TRENDS IN HYDROZOAN BIOLOGY - IV. C.E. MILLS, F. BOERO, A. MIGOTTO and J.M. GILI (eds.)

\title{
Parallel, paedomorphic evolutionary processes of the bivalve-inhabiting hydrozoans (Leptomedusae, Eirenidae) deduced from the morphology, life cycle and biogeography, with special reference to taxonomic treatment of Eugymnanthea*
}

\author{
SHIN KUBOTA \\ Seto Marine Biological Laboratory, Graduate School of Science, Kyoto University, Shirahama, Nishimuro, \\ Wakayama 649-2211, Japan. E-mail: shinkubo@seto.kyoto-u.ac.jp
}

\begin{abstract}
SUMMARY: It is hypothesized that bivalve-inhabiting hydroids originated from colonial, free-living eirenid hydrozoans, initially appearing as an Eutima species with solitary hydroids producing immature medusae with tentacles and manubrium, and also with derived characteristics of the marginal warts of the mature medusae as the remnants of the tentacular bulbs of the ancestral eirenid, and decreased number of statocysts. The derivate eumedusoid-producing Eugymnanthea evolved then. Deduced from the morphology, life cycles, and geographical distributions of this group and of all the known extant Eutima species, it is proposed that parallel, paedomorphic evolution took place in the marginal regions of the area of distribution of the ancestral-like Eutima at least in the northern hemisphere of both the Pacific and the Atlantic Oceans. Eugymnanthea appeared as a polyphyletic taxon as a result of the parallel evolution of different species of Eutima. It is pointed out that Eugymnanthea and Eutima are to be merged into a single genus in the future.
\end{abstract}

Key words: bivalve-inhabiting hydrozoan, paedomorphic, parallel evolution, eirenid, Eutima, Eugymnanthea, life cycle, geographical distribution, polyphyly, taxonomy.

\section{INTRODUCTION}

The most derived bivalve-inhabiting hydrozoan, Eugymnanthea, is distributed disjunctly in the northern hemisphere: E. inquilina Palombi, 1935 has been found in the Mediterranean Sea (Palombi, 1935; Cerruti, 1941; Crowell, 1957; Uchida, 1964; Morri, 1981; Gili, 1986; Kubota, 1989; Piraino et al., 1994; Bouillon et al., 1995; Celiberti et al., 1998; Benovic, personal communication) and $E$. japonica Kubota, 1979 in the Noth-West Pacific

\footnotetext{
*Received December 14, 1999. Accepted July 5, 2000.
}

(Kubota, 1979, 1985a, 1991, 1992b, 1999; Kubota et al., 1999). By combinations of the two diagnostic features of the medusae, manubrium and statolith, the two species of Eugymnanthea can be clearly distinguished (Table 1). There are no records of introduction of Eugymnanthea in any places (Kubota, 1991), differing from the case of their most popular host, Mytilus edulis galloprovincialis Lamarck. In Japanese waters, for instance, $M$. e. galloprovincialis from the Mediterranean Sea settled at the beginning of the $20^{\text {th }}$ century, then spread over nearly all the coasts of Japan except for those of Okinawa Prefecture (Kubota, 1989, 1992b; 
TABLE 1. - Morphological differences between the mature medusae of the two species of Eugymnanthea and their geographical distributions. Fm: frequency (\%) of medusae with manubrium; Nm: number of medusae examined; Fs: frequency (\%) of statocysts containing 1-4 statoliths (Stl); Ns: number of statocysts examined; Nl: number of localities examined.

\begin{tabular}{|c|c|c|c|c|c|c|c|c|c|c|}
\hline \multirow[b]{2}{*}{ Species } & \multirow[b]{2}{*}{$\mathrm{Fm}$} & \multirow[b]{2}{*}{$(\mathrm{Nm})$} & \multicolumn{4}{|c|}{ Fs } & \multirow[b]{2}{*}{$(\mathrm{Ns})$} & \multirow[b]{2}{*}{ N1 } & \multirow[b]{2}{*}{ Distribution } & \multirow[b]{2}{*}{ References } \\
\hline & & & $1 \mathrm{Stl}$ & 2Stl & $3 \mathrm{Stl}$ & $4 \mathrm{Stl}$ & & & & \\
\hline E. japonica & 97.9 & $(4597)$ & 90.2 & 7.4 & 1.1 & 0.1 & $(12955)$ & 21 & Japan (West Pacific) & Kubota, 1991 \\
\hline E. japonica & 95.2 & $(105)$ & 93.0 & 4.3 & 0 & 0 & $(517)$ & 1 & Taiwan (West Pacific) & Kubota, et al., 1999 \\
\hline E. inquilina & 3.4 & (183) & 9.4 & 37.3 & 35.4 & 11.7 & $(1462)$ & 4 & Italy (Mediterranean) & Kubota, 1989 \\
\hline
\end{tabular}

Kubota and Hayashibara, 1995; Kubota et al., 1995; Kubota, 2000).

Kubota $(1987,1989,1991)$, discussing the origin of the two species of Eugymnanthea, discarded both the species introduction and the Tethys Sea relict hypotheses, and proposed the parallel, paedomorphic evolution. Bouillon (1985, 1994) ascribed Eugymnanthea and bivalve-inhabiting Eutima to the Eirenidae, merging the Eutimidae into that family. Monophyly of bivalve-inhabiting hydrozoans is supported also by unpublished data by Kubota, Larson and Migotto who found Atlantic bivalve-inhabiting hydroids producing Eutima medusae. If Eucheilota-like mature medusae are produced in any bivalve-inhabiting hydroids, they will belong to the Eirenidae as is the same case of the intermedia form of Eutima japonica that was firstly described as a new species of Eucheilota, being then considered as one of the four forms of Eutima japonica (Kubota, 1984, 1985b,1992a, 1993, 1997, 1999).

In this paper the evolutionary processes of bivalve-inhabiting hydrozoans leading to the origin of Eugymnanthea are deduced from morphology, life cycles, and geographical distributions. Furthermore, the phylogenetic patterns that led to Eugymnanthea species allow a re-appraisal of the taxonomic value of this nominal genus.

\section{EVOLUTIONARY PROCESSES OF BIVALVE- INHABITING HYDROZOANS}

\section{Early process of evolution}

The ancestral form of the bivalve-inhabiting hydrozoans is conceivable as a free-living eirenid resembling Eirene menoni Kramp (see Bouillon, 1984) or E. lactea (Mayer) (see Brinckmann-Voss, 1973), i.e. a colonial hydroid producing immature medusae with tentacles and manubrium at liberation. Two key character changes took place in this hypothetical ancestor: decrease in number of both the marginal tentacles and the statocysts in the mature medusa (Table 2: 1). It is conceivable that the marginal warts of Eutima medusae are remnants of the tentacular bulbs of the ancestral eirenid medusae.

In Japanese waters, records of Eutima refer only to the bivalve-inhabiting species, E. japonica Uchida, 1925 (Uchida, 1925; Yamazi, 1958; Kubota, 1992a, b, 1998, 1999, unpublished data) and no freeliving species have been known. Other free-living eirenids in Japan are referred to Eirene, Tima and Eutonina (see Kubota, 1998). Eutima japonica, representing what could have been the ancestor of Eugymanthea japonica, is divided into the four forms that are parapatrically distributed, changing their morphology of the earliest matured medusae step by step (Kubota, 1992a, 1997, 1999). The medusa of Eutima japonica was also collected in the central part of the north Pacific (Kramp, 1965), Cochin Backwater, India (Santhakumari et al., 1971), and in the Jiulong River estuary near Amoy, China (Zhenzu and Jiachi, 1983). It was never found in the east coasts of the Pacific, from where no bivalve-inhabiting hydrozoans have been recorded yet, in spite of recent surveys conducted in Central and Southern California, USA (Kubota, unpublished data). It is assumed that the water temperature is too low for this group to settle, since the coasts are usually washed by cold currents.

Some planktonic Eutima species have been described from the Mediterranean Sea (Boero and Bouillon, 1993; Fig. 1), but ancestral-like bivalveinhabiting Eutima have not been found, even in recent surveys carried out in Italy, Croatia and Spain (Kubota, unpublished data). However, in the west coasts of the Atlantic Ocean, in both northern and southern hemisphere, bivalve-inhabiting Euti$m a$ have been reported (Mattox and Crowell, 1951; Narchi and Hebling, 1975; Kubota and Larson, 1990; Kubota et al., unpublished data), though Eugymnanthea has not been recorded from this region. 
TABLE 2. - Parallel evolutionary processes (1-3) producing the bivalve-inhabiting hydrozoans, showing some extant representatives. (1) Decrease of number of statocysts and tentacles; (2) Evolution of sucker-like hydrorhiza and disappearance of periderm; (3) Evolution of eumedusoids; * Eirene hexanemalis is another possibility.

\begin{tabular}{|c|c|c|c|c|}
\hline $\begin{array}{l}\text { Region } \\
\text { (Oceans and their } \\
\text { marginal seas) }\end{array}$ & $\begin{array}{l}\text { Exsistence of } \\
\text { ancestral-like } \\
\text { free-living Eirene }\end{array}$ & $\begin{array}{l}\text { Evolution of } \\
\text { free-living } \\
\text { Eutima }\end{array}$ & $\begin{array}{l}\text { Evolution of } \\
\text { bivalve-inhabiting } \\
\text { Eutima }\end{array}$ & $\begin{array}{l}\text { Evolution of derivative } \\
\text { Eugymanthea } \\
\text { by progenesis }\end{array}$ \\
\hline $\begin{array}{l}\text { Atlantic } \\
\text { Pacific }\end{array}$ & $\begin{array}{l}\text { Eirene lactea } \\
\text { Eirene menoni* }\end{array}$ & $\begin{array}{l}\text { (1) Eutima mira } \\
\text { (1)? }\end{array}$ & $\begin{array}{l}\text { (2) Eutima sapinhoa } \\
\text { (2) Eutima japonica }\end{array}$ & $\begin{array}{l}\text { (3) Eugymnanthea inquilina } \\
\text { (3) Eugymnanthea japonica }\end{array}$ \\
\hline
\end{tabular}

\section{The evolution of the most derived bivalve- inhabiting hydrozoan Eugymnanthea}

From the free-living, colonial Eutima, the solitary, bivalve-inhabiting hydroid evolved without drastic modification of the medusa stage, and appeared as a specialized, distinct member in the Eirenidae as mentioned above. The hydrorhiza changed into a sucker-like structure from the stolon in order to attach to the surface of the living, soft body portions of the bivalve hosts. The periderm disappeared in these hydroids in relation to the endosymbiotic life within the mantle cavity of the hosts (Table 2: 2). Such an evolution occurred parallely both in the Atlantic Ocean and in the Pacific and their marginal seas, producing primitive bivalveinhabiting Eutima (Kubota, 1987, 1991). In the Pacific, a different hydroid morphotype, i.e. a branched, solitary one with hydrorhiza penetrating into the host tissues, appeared in specialised woodboring host bivalves (Santhakumari and Balakrishnan Nair, 1969; Ramachandra et al., 1974; Kalyanasundaram, 1975). The medusae of this species were recorded from the Cocin Backwater, India, where the hydroids were also recorded (Santhakumari, 1970), Bombay harbour, India (Santhakumari, et al., 1971, 1977), and the Red Sea (Schmidt, 1973). Including E. commensalis Santhakumari, 1970, all the bivalve-inhabiting Eutima in the Pacific possess cirri in the medusa stage, contrary to the bivalveinhabiting Eutima in the Atlantic Ocean (Kubota, 1987; Kubota and Larson, 1990; Kubota et al., unpublished data).

Boero et al. (1996) hypothesized another possible origin of bivalve-inhabiting Eutima, i.e. from a free-living, solitary, planktonic eirenid hydroid resembling Eirene hexanemalis (Goette) (see Bouillon, 1983). Such floating hydroids are rare at present and the only other species with this feature is Zelounies estrambourdi (see Gravier-Bonnet, 1992). It is possible that both types of ancestral-like hydrozoans produced independently the special hydrorhizas for the endosymbiotic life with bivalves. The invasive developmental stage of the bivalve-inhabiting hydrozoans is a solitary planula, therefore a particular ability of this larva to settle on the living tissues of bivalves, which are often covered by a mucous layer and moving cilia, should be acquired. However, this was accomplished during the course of evolution of this group like other endosymbiotic hydrozoans with ascidians, Ascidioclava (see Kubota and Yamada, 1988) or with bryozoans (Boero et al., 2000).

From the bivalve-inhabiting hydrozoans with sucker-like hydrorhiza, Eugymnanthea-like species evolved independently by progenesis, at least in the northern hemisphere of the Pacific and of the Atlantic Ocean and its marginal seas, appearing as the most derived and aberrant thecate hydrozoans (Table 2: 3). These hydroids produce eumedusoids without marginal tentacles and ordinary manubrium that go out from the mantle cavity of the hosts to quickly spawn in the sea (Palombi, 1935; Kubota, 1996). Their life span is short and all life is spent near the host. No bivalve-inhabiting hydrozoans producing sporosacs have been found, but at low temperature Eugymnanthea eumedusoids are not released (cf. Kubota, 1979, 1987).

According to Boero and Bouillon (1993), among the members of the Mediterranean hydromedusae with hydroid stage, the Indo-Pacific element is not abundant, i.e. only 28 species $(8.0 \%)$ out of 346 . This geographical element is thought to be originated by the migration through the Suez Canal (the Lessepsian migration). However, the genus Eugymnanthea can not be included into this zoogeographical element, and the Mediterranean Eugymnanthea is considered as endemic by Boero and Bouillon (1993). The origin of the Mediterranean-endemic element is ascribed to essentially three causes: the relict of the Tethys Sea fauna; speciation from species that colonised the basin after the Messinian crisis; 'false endemics' due to lack of knowledge of zoogeographical and/or taxonomic informations. 


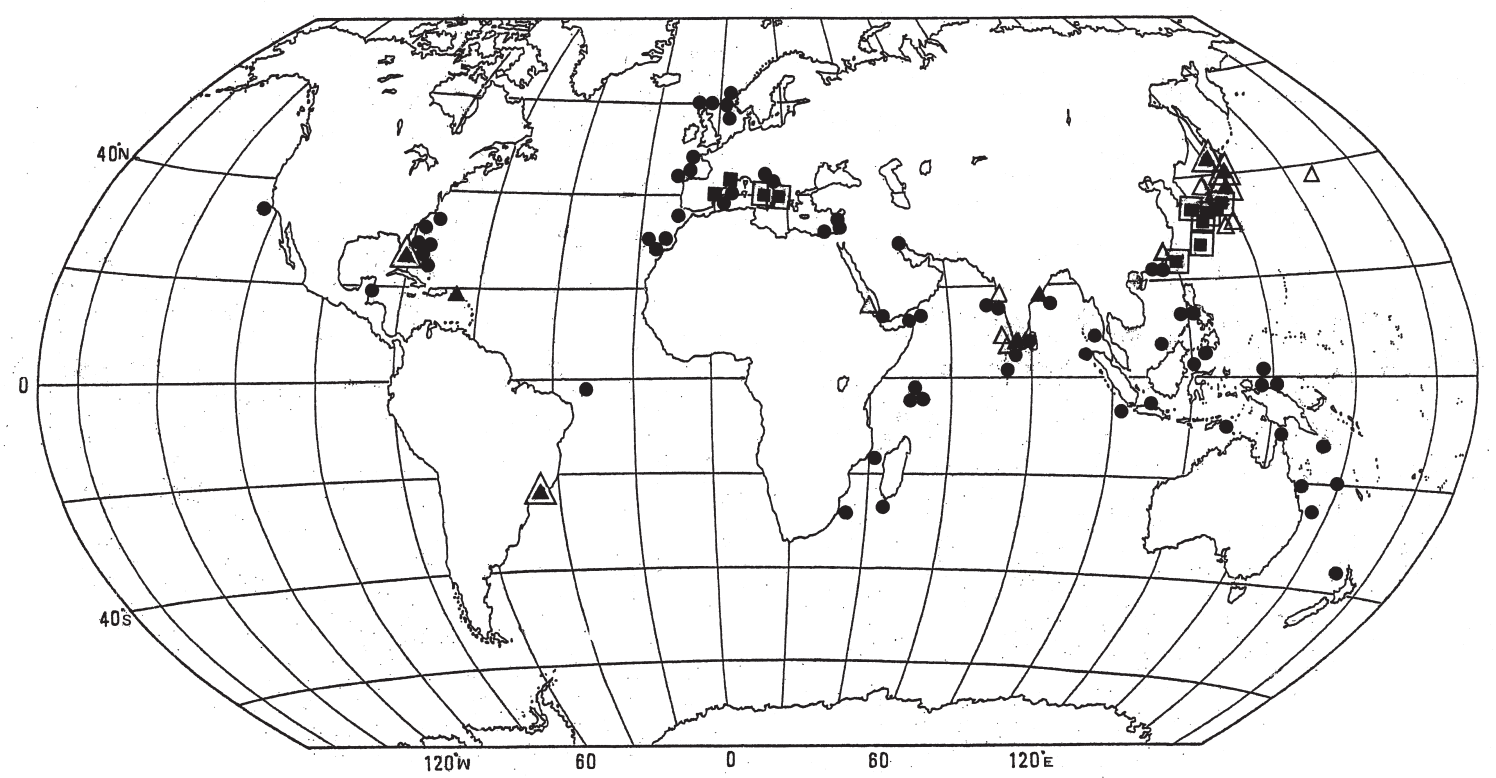

FIG. 1. - Geographical distribution of planktonic medusae of bivalve-inhabiting Eutima (E. japonica and E. commensalis: open triangles), hydroids of bivalve-inhabiting Eutima (at least 4 species: closed triangles), hydroids of Eugymnanthea (2 species: closed rectangles), and planktonic extant Eutima medusae (closed circles: after many references, but not cited everyone and confer van der Spoel, 1996). Doublefold symbols indicate mature medusae of the bivalve-inhabiting hydroids are known by culture.

However, the origin of the Mediterranean Eugymnanthea inquilina is entirely unknown. An ancestral type of bivalve-inhabiting hydrozoans, corresponding to the Pacific Eutima japonica, has not been discovered in the Mediterranean and also in the east coast of the Atlantic Ocean.

Deduced from the geographical distributions of the bivalve-inhabiting hydrozoans and all the known extant Eutima species, the above-mentioned processes of the parallel, paedomorphic evolution occurred in the marginal regions of the distributed area of the ancestral-like Eutima species (Fig. 1), although there is a problem that most of the hydroid stages of the extant Eutima are still unknown (Table 2). The center of origin of the leptomedusae, the Indo-Malayan region pointed out by van der Spoel (1991, 1996), may not be a suitable location to promote the progenetic evolution leading to the production of Eugymnanthea and there are no records of this genus in this region (Kubota, unpublished data; Ho, pers. comm.). Kubota (1987) speculated that this convergent evolution was induced in the Pacific and the Atlantic Oceans and their marginal seas by climatic changes, i.e. cool and/or cold environment in the Pleistocene. If this progenetic evolution produced identical morphological forms of Eugymnanthea in two or more different remote places, as the mosaic evolution of the hydrozoans often takes place in different taxonomic groups (Boero and Bouillon, 1987; Petersen, 1990), we deduce the origin of the
Pacific Eugymnanthea as a mere introduction from the Mediterranean Sea together with its host Mytilus edulis galloprovincialis.

\section{Eugymnanthea, together with at least bivalve- inhabiting Eutima, could be merged into the one same genus}

The genus Eugymnanthea is traditionally defined on morphology (Bouillon, 1985, 1994). If the above-mentioned origin of this genus in the Eirenidae is demonstrated, then a taxonomic problem related to phylogeny turns out. General evolutionary processes producing bivalve-inhabiting Eutima and Eugymnanthea are acceptable, and the phylogenetic tree is depicted as shown in Fig. 2A (Kubota, 1983; Boero, Bouillon and Piraino, 1996). This phylogeny does not conflict to the hypotheses of the Tethys Sea relict and the species introduction, and no taxonomic problems turn out from this tree. However, in the case of parallel evolution a more precise phylogenetic tree is shown in Fig. 2B. In this tree the bivalve-inhabiting Eugymnanthea appeared as a polyphyletic genus. Taxonomic treatment of assigning all the bivalve-inhabiting Eutima and Eugymnananthea into the one genus is, therefore, reasonable. In this paper, however, formal taxonomic changes according to the international nomenclatural rules are not made until more biological studies are made and we confirm the origin of Eugymnanthea (Kubota et al., in prep.). 


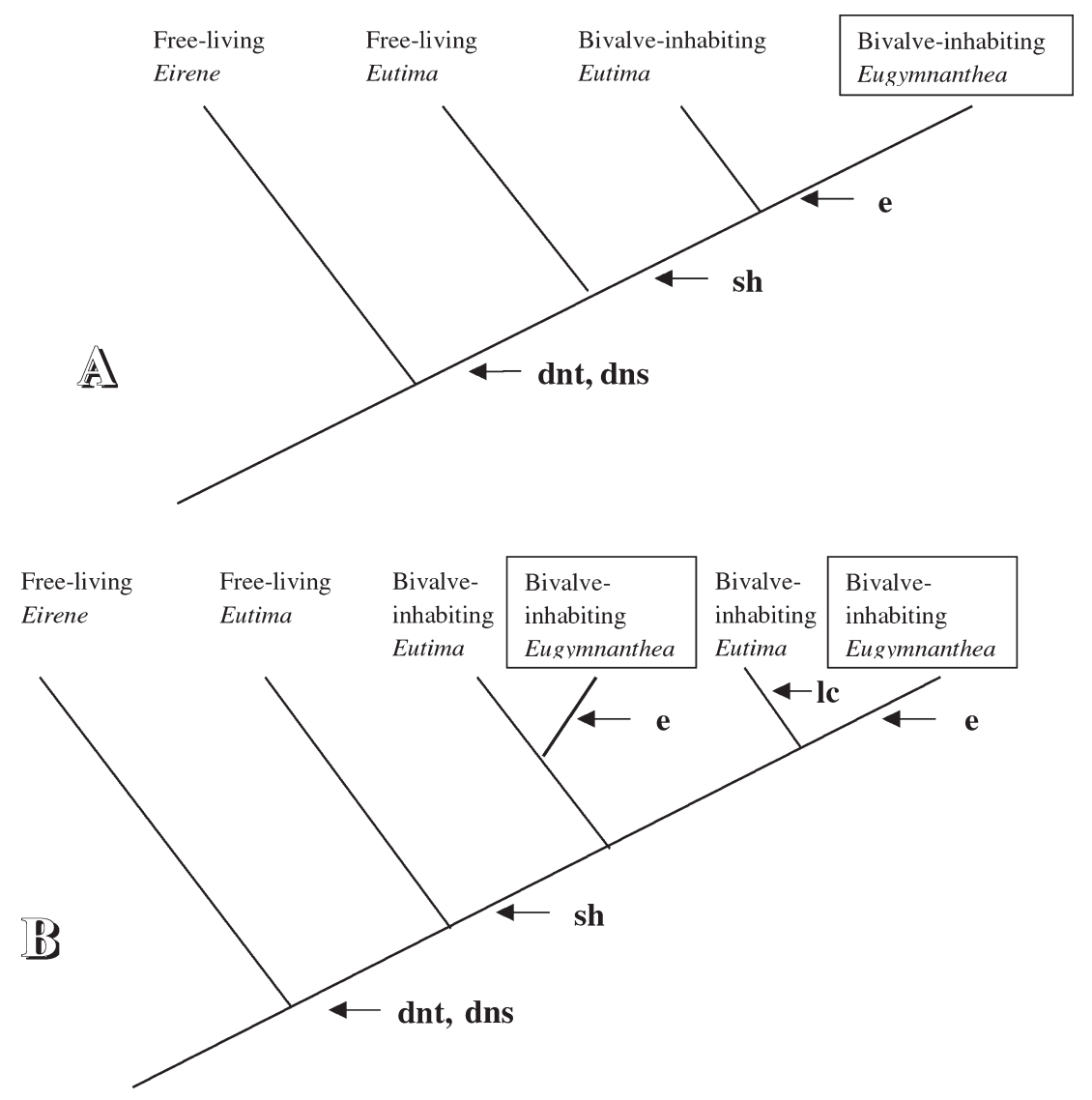

FIG. 2. - A: Phylogenetic tree showing general evolutionary courses of the bivalve-inhabiting hydrozoans in Eirenidae. B: Phylogenetic tree showing bivalve-inhabiting Eugymnanthea originated by parallel, progenetic evolution, resulting polyphyly. dns: decrease of the number of statocysts, dnt: decrease of the number of tentacles, e: production of eumedusoid, sh: production of sucker-like hydrorhiza, lc: loss of cirri.

It is generally admitted that the metagenic hydrozoans like bivalve-inhabiting ones are difficult to manage to establish an appropriate classification (Kubota, 1983; Boero and Bouillon, 1987). In the athecate groups producing eumedusoids, Petersen (1990) pointed out that production of either fixed gonophores or of eumedusoids is not a key character to define genera. Convergent evolution producing eumedusoids took place in many branches of diverse taxonomic groups. The same conclusion was obtained by a molecular apporoach on the Hydractiindae by Cunningham and Buss (1993). Therefore, similar studies are needed for bivalve-inhabiting hydrozoans, and they will shed light in the phylogeny and taxonomy of this group.

The phylogeny of Eirenidae, a family comprising 12 genera (Bouillon, 1985, 1994), is not easy mainly due to lack of knowledge of life cycles. Bouillon (1985) considered the related hydrozoans to the Eirenidae are Lovenellidae, Eucheilotidae and Cirrholoveniidae, therefore all these hydrozoans should be taken into account to clarify the phylogeny of the present group. Much care is needed to select outgroups since such choices greatly change the resultin phylogenies, as pointed out by Boero et al. (1997).

\section{ACKNOWLEDGEMENTS}

The author wishes his heartfelt thanks to Prof. Ferdinando Boero for his critical reading of the manuscript, valuable suggestions, and allowing a hurricane-like survey in his big library of hydrozoans. The author also thanks Drs. Ron J. Larson, Alvaro E. Migotto, Adam Benovic, Ju-shey Ho for their allowance to mention their unpublished data. The author wishes his sincere thanks to Dr. F. G. Hochberg and the staff of the Bodega Marine Laboratory for their kind help to collect Mytilus and allow use of their facilities. The author thanks Prof. Jean Bouillon and Dr. Claude Massin for their kindness to loan specimens deposited in the Institut royal des Sciences naturelles de Belgique. Dr. Maria Pia Miglietta kindly prepared Figure 2. 


\section{REFERENCES}

Boero, F. and J. Bouillon. - 1987. Inconsistent evolution and paedomorphosis among the hydroids and medusae of the Athecatae/Anthomedusae and the Thecatae/Leptomedusae (Cnidaria, Hydrozoa). In: J. Bouillon, F. Boero, F. Cicogna and P.F.S. Cornelius (eds.), Modern trends in the systematics, ecology and evolution of hydroids and hydromedusae, pp. 251-256. Oxford University Press, London.

Boero, F. and J. Bouillon. - 1993. Zoogeography and life cycle patterns of Mediterranean hydromedusae (Cnidaria). Biol. J. Linn. Soc., 48: 239-266.

Boero, F., J. Bouillon and S. Piraino. - 1996. Classification and phylogeny on the hydroidomedusae (Hydrozoa, Cnidaria). Sci. Mar., 60: 17-33.

Boero, F., J. Bouillon and P. Piraino. - 1997. Heterochrony, generic distinction and phylogeny in the family Hydractiniidae (Hydrozoa: Cnidaria). Zool. Veerh. Leiden, 323: 25-36.

Boero, F., J. Bouillon and C. Gravili. - 2000. A survey of Zanclea, Halocoryne and Zanclella (Cnidaria, Hydrozoa, Anthomedusae, Zancleidae) with description of new species. Ital. J. Zool., 67: 93-124.

Boero, F., J. Bouillon, S. Piraino and V. Schmid. - 1997. Diversity of hydroidomedusan life cycles: ecological implications and evolutionary patterns. Proc. $6^{\text {th }}$ Intern. Conf. Coelenterate Biol., 1995: 53-62.

Bouillon, J. - 1983. Sur le cycle biologique de Eirene hexanemalis (Goette, 1886) (Eirenidae, Leptomedusae, Hydrozoa, Cnidaria). Cah. Biol. Mar., 24: 421-427.

Bouillon, J. - 1984. Hydromeduses de la Mer de Bismarck (Papouasie Nouvelle-Guinee. Partie IV: Leptomedusae (Hydrozoa-Cnidaria). Indo-Malayan Zool., 1: 25-112.

Bouillon, J. - 1985. Essai de classification des HydropolypesHydromeduses (Hydrozoa-Cnidaria). Indo-Malayan Zool., 2(1): 29-243.

Bouillon, J. - 1994. Cnidaires. Hydrozoaires Scyphozoaires Cubozoaires Ctenaires. Traite de Zoologie. Masson, Paris. 1117 pp.

Bouillon, J., C. Massin and R. Kresevic. - 1995. Hydroidomedusae de I'insitut royal des Sciences naturelles de Belgique. Van Ghoethem, J. (ed.), Edition de I'Inst. royal Sci. Nat. Belgique, 78: $1-106$.

Brinckmann-Voss, A. - 1973. The life-cycle of Eirene lactea (Mayer, 1900) and Helgicirrha schulzei Hartlaub, 1909 (Phylum Cnidaria, Class Hydrozoa, Order Leptomedusae, Family Eirenidae). Publ. Seto Mar. Biol. Lab., 20 (Proc. $2^{\text {nd }}$ Int. Symp. Cnidaria): 63-72.

Celiberti, M.E., S.Piraino, P. Pagliara and F. Boero. - 1998. Specializzazione dell'habitat ed ermafroditismo simultaneo in Eugymnanthea inquilina (Hydrozoa). Biol. Mar. Medit., 5(1): 537-539.

Cerruti, A. - 1941. Mytilhydra polimantii n. gen., n. sp. idroide vivente sul mantello dei mitili. Riv. Biol., 32: 1-18.

Crowell, S. - 1957. Eugymnanthea, a commensal hydroid living in pelecypods. Pubbl. Staz. Zool. Napoli, 30: 162-167.

Cunningham, C.W. and L.W. Buss. - 1993. Molecular evidence for multiple episodes of paedomorphosis in the family Hydractiniidae. Biochem. Syst. Ecol., 21(1): 57-69.

Gili, J.-M., 1986. Estudio sistematico y faunistico de los cnidarios de la costa Catalana. PhD thesis, Auton. Univ. of Barcelona. $565 \mathrm{pp}$.

Gravier-Bonnet, N. - 1992. Cloning and dispersal by buoyant autotomised hydranths of a thecate hydroid (Cnidaria; Hydrozoa). Sci. Mar., 56(2-3): 229-236.

Kalyanasundaram, N. - 1975. Studies on the biology of Mytilopsis sallei (Recluz), an important marine fouling mollusc. Bull. Dept. mar.Sci. Univ. Cochin, 7: 685-693.

Kramp, P.L. - 1965. The hydromedusae of the Pacific and Indian Oceans. Dana Reports, 63: 1-162.

Kubota, S. - 1979. Occurrence of a commensal hydroid Eugymnanthea inquilina Palombi from Japan. J. Fac. Sci. Hokkaido Univ., Ser. 6, Zool., 21: 396-406.

Kubota, S. - 1983. Studies on life history and systematics of the Japanese commensal hydroids living in bivalves, with references to their evolution. J. Fac. Sci. Hokkaido Univ. Ser. 6, Zool., 23: 296-402

Kubota, S. - 1984. A new bivalve-inhabiting hydroid from central Japan, with reference to the evolution of the bivalve-inhabiting hydroids. J. Fac. Sci. Hokkaido Univ. Ser. 6, Zool., 23(4): 454-467.

Kubota, S. - 1985a. Systematic study on a bivalve-inhabiting hydroid Eugymnanthea inquilina japonica Kubota from central Japan. J. Fac. Sci. Hokkaido Univ., Ser. 6, Zool., 24(1): 70-85.

Kubota, S. - 1985b. Systematic study on a bivalve-inhabiting hydroid Eucheilota intermedia Kubota from central Japan. J. Fac. Sci. Hokkaido Univ., Ser. 6, Zool., 24(2): 122-143, pl. I.

Kubota, S. - 1987. The origin and systematics of four Japanese bivalve-inhabiting hydroids. In: J. Bouillon, F. Boero, F. Cicogna and P.F.S. Cornelius (eds.), Modern trends in systematics, ecology, and evolution of hydroids and hydromedusae, pp. 275-287. Oxford University Press, London.

Kubota, S. - 1989. Systematic study of a paedomorphic derivative hydrozoan Eugymnanthea (Thecata-Leptomedusae). Zool. Sci., 6: 147-154.

Kubota, S. - 1991. The stability of diagnostic characters of the medusa of a bivalve-inhabiting hydrozoan Eugymnanthea japonica Kubota in Japan. Proc. Japn. Soc. Syst. Zool., 44: 1-7.

Kubota, S. - 1992a. Eucheilota intermedia Kubota is a distinct taxon and the third form of Eutima japonica Uchida (Hydrozoa; Leptomedusae). Zool. Sci., 9: 231-235.

Kubota, S. - 1992b. Four bivalve-inhabiting hydrozoans in Japan differing in range and host preference. Sci. Mar., 56(2-3): 149-159.

Kubota, S. - 1993. The second example of metamorphosis of the medusa from the intermedia form to the southern form in Eutima japonica (Leptomedusae, Eirenidae). Publ. Seto. Mar. Biol. Lab., 36(1/2): 95-97.

Kubota, S. - 1996. Timing of medusa release in a hydroid Eugymnanthea japonica (Cnidaria, Leptomedusae, Eirenidae) commensal with a mussel. Sci. Mar., 60(1): 85-88.

Kubota, S. - 1997. A new form of the bivalve-inhabiting hydrozoan Eutima japonica (Leptomedusae, Eirenidae) in Japan. Publ. Seto Mar. Biol. Lab., 38(1/2): 73-81.

Kubota, S. - 1998. A list of hydrozoans (8 orders) in Japan. Nankiseibutu, 40(1): 13-21.

Kubota, S. - 1999. Biogeographical study on bivalve-inhabiting hydrozoans (Cnidaria, Hydrozoa) in Japan. In: Okutani, T., Ohta, S. and Ueshima, R. (eds.), Updated Progress in Aquatic Invertebrate Zoology, pp. 35-39, Tokai Univ. Press, Tokyo, Japan. (In Japanese)

Kubota, S. - 2000. Reappearance of Mytilus edulis galloprovincialis (Mollusca, Bivalvia) on the shore of Akajima, the Kerama Islands. Midoriishi, 11: 4. (In Japanese)

Kubota, S. and Y. Hayashibara. - 1995. Many specimens of Mediterranean blue mussel (Mollusca, Bivalvia) drifted ashore on the coasts of Akajima Island, the Kerama Islands. Midoriishi, 6: 17-19. (In Japanese)

Kubota, S. and R.J. Larson. - 1990. The first record of a bivalveinhabiting hydrozoan from USA. Proc. Japn. Soc. Syst. Zool., 41: $1-4$.

Kubota, S. and M. Yamada. - 1988. The first record of a hydroid endosymbiotic with an ascidian in the western Pacific. Proc. Japn. Soc. Syst. Zool., (38): 1-5.

Kubota, S., T. Yamamoto and F. Nozaki. - 1995. Mediterranean blue mussel (Bivalvia, Mytiloida) collected from Sakurajima and Yakushima Islands -On the southernmost distributed place in this species in Japan-. Nankiseibutu, 37(2): 135-136. (In Japanese)

Kubota, S., C.-F. Dai, C.-L. Lin and J.-S. Ho. - 1999. The first occurrence of the paedomorphic derivative hydrozoan Eugymnanthea from Taiwan, with a report of a new host. Publ. Seto. Mar. Biol. Lab., 38(5/6): 219-222.

Mattox, N.T. and S. Crowell. - 1951. A new commensal hydroid of the mantle cavity of an oyster. Biol. Bull., 101: 162-170.

Morri, C. - 1981. Guide per il riconoscimento delle specie animali delle acque lagunai e costiere italiane. AQ/I/94 6. Idrozoi lagunari. Consiglio Nazionale delle Ricerche: 1-105.

Narchi, W. and N.J. Hebling. - 1975. The life cycle of the commensal hydromedusa Eutima sapinhoa n. sp. Mar. Biol., 30: 73-78.

Palombi, A. - 1935. Eugymnanthea inquilina nuova leptomedusa derivante da un atecato idroide ospite intero di Tapes decussatus L. Pubbl. Staz. Zool. Naooli, 15: 159-168.

Petersen, K. - 1990. Evolution and taxonomy in capitate hydroids and medusae (Cnidaria: Hydrozoa). Zool. J. Linnean Soc., 100: 101-231.

Piraino, S., C. Todaro, S. Geraci and F. Boero. - 1994. Ecology of the bivalve-inhabiting hydroid Eugymnanthea inquilina in the 
coastal sounds of Taranto (Ionian Sea, SE Italy). Mar. Biol., 118: 695-703.

Ramachandra Raju, P.K. Mangapathi Rao, and N. Kalyanasundaram. - 1974. Occurrence of a commensal hydroid Eugymnanthea sp. in a marine fouling mollusc Congeria sallei Recluz (Pelecypoda). Current Sci., 43(2): 52-53.

Santhakumari, V. - 1970. The life cycle of Eutima commensalis sp. nov. (Eutimidae, Hydromedusae). Mar. Biol., 5: 113-118.

Santhakumari, V. and N. Balakrishnan Nair. - 1969. A commensalic hydroid from wood-boring molluscs. J. nat. Hist. 3: 19-33

Santhakumari, V. and M. Vannucci. - 1971. Monsoonal fluctuations in the distribution of the hydromedusae in the Cochin backwater, 1968-1969. J. mar. biol. Ass. India, 13(2): 211-219.

Santhakumari, V., Neelam Ramaiah and Vijayalakshmy R. Nair. 1997. Ecology of hydromedusae from Bombay harbour Thana and Bassein creek estuarine complex. Indian J. Mar Sci., 26: 162-168.
Schmidt, H.-E. - 1973. Die Hydromedusen (Hydrozoa: Coelenterata) des Roten Meeres und seiner angrenzenden Gebiete. "Meteor" Forsch.-Ergebnisse, D, 15: 1-35.

Van der Spoel, S. - 1991. Hydromedusan distribution patterns. Hydrobiologia, 216/217: 489-496.

Van der Spoel, S. - 1996. A hypothesis on Mesozoic vicariance in hydromedusae. J. Plankton Res., 18(4): 615-634.

Uchida, T. - 1925. Some hydromedusae from northern Japan. Jap. J. Zool., 77-100.

Uchida, T. - 1964. Medusae of Eugymnanthea, an epizoic hydroid. Publ. Seto. Mar. Biol. Lab., 12: 101-107.

Yamazi, I. - 1958. Preliminary check-list of plankton organisms found in Tanabe Bay and its environs. Publ. Seto Mar. Biol. Lab., 7: 111-163.

Zhenzu, Xu and H. Jiachi. - 1983. On the hydromedusae, siphonophora, scyphomedusae and ctenophora from the Jiulong River estuary of Fujian, China. Taiwan Strait, 2: 99-110. 